\title{
INDUSTRIAL CHANGE AND THE PROGRESS OF LABOR IN THE ENGLISH COTTON INDUSTRY
}

\section{INTRODUCTION}

By the time labor unrest in the Lancashire cotton industry had taken the form of the strike, trade-union development was being hindered by the Combination Laws of 1799-1800, which were to outlaw unions of workers (and supposedly employers) until their repeal in 1824-25. Although the cotton operatives resorted to the strike weapon during this period, the movements were indeed dismal failures. While the Lancashire handloom weavers seem to have won partial concessions from their employers in 1808 , the raises were only temporary, and the weavers remained in their state of almost habitual poverty until being extinguished as a class of workmen by the power-loom. ${ }^{1}$ And the spinners, whose unions were noted for their superior organization, failed entirely in their strikes of 1810 and 1818. Given this set of circumstances, labor historians Sidney and Beatrice Webb have stressed the "ephemeral combinations" of the early cotton workers and their "passionate struggles to maintain a bare subsistence wage", alternating with "intervals of abject submission". ${ }^{2}$ Similarly, G. D. H. Cole has depicted the textile workers, along with the miners, as "latecomers to trade unionism". 3

However, in judging these expressions of worker discontent solely from the standpoint of ultimate effectiveness, there is a tendency to overlook significant similarities and differences in the nature of labor unrest in two distinct forms of industrial organization. The weaving

1 Curiously, there exists no clear record of the final terms accepted by the weavers in 1808 . Richard Needham, a weaver, merely observed that the strikers, demanding a $33 \frac{1}{8} \%$ raise, got a $20 \%$ increase "for about one month, and then it all tumbled to ruins again". See Report of the Select Committee on Handloom Weavers' Petitions [Parliamentary Papers, 1834, X], p. 426.

2 Sidney and Beatrice Webb, The History of Trade Unionism (London, 1920), p. 87.

3 G. D. H. Cole, An Introduction to Trade Unionism (London, 1953), p. 53. 
industry of the first quarter of the 19th century was predominantly a putting-out or domestic system. Since the late 16th century the independent textile worker, who bought the raw materials and sold the final product of his labor, was being gradually cut off from direct access to the sources of raw materials and the final markets by the intervention of merchant middlemen. ${ }^{1}$ With the full development of the putting-out system by 1700 , the laborers had clearly relinquished ownership of moving capital (raw materials) and were thus more clearly differentiated as a class of workers than the handicraft weavers of the 16th century. But for the most part, here the weaving industry remained through at least the first 25 years of the 19 th century as the weavers continued to labor in their own homes and on looms which they either owned or rented. On the other hand, the spinning industry by the advent of the 19th century was based almost exclusively on factory production. With the adoption of the jenny, water-frame, and mule, the ownership of fixed capital (tools and premises), as well as circulating capital, passed to the employer. The alienation of capital from labor was now complete, and in the process operatives were brought together to labor in their employers' establishments.

It stands to reason that between these two industrial forms, which imply differences in the status of labor, there should exist differences in the processes and mechanisms of worker unrest. For example, as relatively large sums of capital in the form of buildings and machinery came into the possession of the employer, we might expect labor unrest within the factory system to display a militantly anti-capitalistic nature. The workers would be in a position to use this capital investment as a bargaining weapon against the employer. Especially considering the inefficiency of the English police before 1830, this trend can be revealed in a strike by the threatened destruction of factories whose owners attempted to hire strike-breakers. Under a putting-out system like handloom weaving, attacks on competing looms would be threats to the property of the workers and thus a less formidable mechanism against the capitalist class. Moreover, as the workers were developing and expressing their identity vis-a-vis the capitalist, the process was complemented by a growing sense of solidarity, enhanced by the relative concentration of the factory labor force. We can gain insight into this development by examining the general organization of the strike movements and their systems of mutual support embodied in strike funds. Therefore, in the following analysis

1 For the early development of the cotton industry, see A. P. Wadsworth and J. Mann, The Cotton Trade and Industrial Lancashire, 1600-1780 (Manchester, 1931); C. W. Daniels, The Early English Cotton Industry (Manchester, 1920). 
of the principal cotton strikes before 1824 we will be less concerned with the ultimate success or failure of the labor movements than with the problems of industrial change and the growth of modern trade union methods. To what extent and in what ways did the processes and mechanisms of labor unrest within the emerging factory system differ from those of the more traditional putting-out system?

\section{I}

In order to orient ourselves for a rather detailed analysis, perhaps we should begin with a general narrative of the strike movements under consideration in this essay. The first strike of the Lancashire cotton weavers began in the depression year of 1808 on May 24, following the rejection by Parliament of the weavers' petition for a minimum-wage bill. Manchester historian, Archibald Prentice, was impressed by the solidarity and peacefulness of the strikers during their meetings on St George's Field in Manchester on the 24th and 25th of May. ${ }^{1}$ However, communication between the various weaving districts seems to have been less than ideal since it was not until May 27 that the strike had spread from the Manchester area to the calico-weaving districts of Northern Lancashire. The workers initially demanded a $33 \frac{1}{3} \%$ increase in their wages, and while this request was rejected by the employers, most of them agreed to a $20 \%$ raise shortly after the commencement of the strike. This concession had an almost immediate impact on the movement; as early as May 31, Mr R. A. Farington, Justice of the Peace of Manchester, could write to the Home Office: "We have reason to believe there is now a strong division among the leaders of the weavers, that is, between those satisfied with the results of yesterday and those who differ in opinion." 2 Within three days, many of the Manchester weavers who were content with the $20 \%$ raise began to return to their looms. The early solidarity of the weavers in the Manchester vicinity was now overshadowed by assaults upon the working operatives. This intimidation seems to have taken the form of shuttle gathering accompanied by threats of violence. Moreover, while the strike was over in the Manchester area by June 9, as late as the 13th Farington noted: "The weavers in many parts are yet discontented." 3 The strike continued in Northern Lancashire until the end of June.

1 Archibald Prentice, Historical Sketches and Personal Recollections of Manchester (London, 1851), pp. 30-34.

${ }^{2}$ Home Office Papers 42/95, also in A. Aspinall, The Early English Trade Unions (London, 1949), No 92, pp. 97-98.

${ }^{3}$ HO 42/95, Aspinall, op. cit., No 100, p. 102. 
The second and last Lancashire handloom weavers' strike took place in 1818 and exhibited developments very similar to those of 1808. Requesting a raise of 7 shillings, the operatives in Manchester quit work on September 1. As in 1808, the weavers demonstrated solidarity during the early days of the strike when they adopted the impressive method of marching through the streets of Manchester to the tune of a fife. The weavers, after assembling in Manchester, walked en masse through the neighboring districts to bring out their people there. There was very little violence during the first week of the strike. However, the movement had not spread to the more distant areas of the North until September 5. A general delegate meeting was held in Bury on the 5th when a coalition led by R. Ellison, R. Pilkington and $\mathrm{J}$. Kay attempted to bind the entire weaving force to the whole demand of 7 shillings. By the time of the Bury meeting, however, the employers of Manchester, Bolton and Oldham had agreed to a partial raise of $3 / 6 \mathrm{~d}$, the remainder to be paid one month later. The following days of the strike were thus marked by altercations between those still on strike and an increasing number of weavers satisfied with the $3 / 6 \mathrm{~d}$ increase. As in 1808, the strikers visited weavers at their homes and demanded their shuttles under threats of violence. Furthermore, while the 1818 strike had been broken in the Manchester area by September 11, the movement was at that time at its strongest in the North and was adopting more violent methods. As late as the 17th, Dr T. D. Whitaker could still inform Viscount Dismouth that "The Hundred of Blackburn is in a state approaching to that of a general insurrection in consequence of a dispute betwixt the weavers and their employers on the subject of wages." 1 It was not until September 22 that peace was restored to the Northern vicinity.

The Lancashire cotton spinners first struck in 1810 in what one contemporary described as the most extensive and perseverant strike ever, and one which, if allowed to continue, "both Carlisle and Scotland would have joined". ${ }^{2}$ The spinners all quit work on the same day early in January, after having given their employers a two-week notice. The objective was to raise the rates of the country districts to the level paid in Manchester. The relatively superior organization of the spinners is revealed by the Union Congress, which coordinated the strike. Composed of delegates from all the principal mills, the Congress established a rule that no factory strike without the sanction of the entire Union. Furthermore, the strike was generously supported by

1 HO 42/180, Aspinall, No 302, p. 300.

2 Report from the Committee on Artizans and Machinery [Parliamentary Papers, 1824, V], p. 409. 
funds from all of the factories in Lancashire. While there was undoubtedly intimidation held out to prospective strike-breakers, E. C. Tufnell, a contemporary, noted also that "Attacks were frequently made on the factories" and "many masters were unable to leave their mills, for fear of their lives". ${ }^{1}$ The strike lasted about four months, before a depletion of their funds forced the spinners back to work.

The next strike of the spinners took place in 1818. As in 1810 , the workers all struck at once on July 18, after having given their employers a fortnight notice. Their organization evidently impressed Sir John Byng, who wrote:

"Their regular meeting and again dispersing shows a system and organization of their actions which has some appearance of previous tuition. The evil appears to extend from town to town, but not to decrease in any place." 2

Effective communication between the manufacturing districts is also revealed by the workers' tactic of sending strikers from their own mills to other areas in an attempt to prevent anyone from entering the factories. When factory owner James Frost was asked in 1824 why he was unable to aid the authorities in prosecuting the 1818 strikers under the Combination Acts, he mentioned the above action, declaring that "it was impossible for us to identify the most active; the same faces never making their appearance a second time, and they always took care to send people we did not know from the other side of town." 3 Mr Frost also recalled that the spinners had scouts stationed throughout the districts to watch for the police. Frost noted that men attempting to enter the factories were hoisted on the strikers' shoulders and exposed to derisive namecalling. But he added that, like the 1810 strike, the 1818 movement was characterized by many assaults on mills. The strike was also subsidized by funds, including support from other trades. The 1818 spinners' strike, which began with the primary goal of restoring wages to the 1814 level, was not ended until September 7, again the result of a shortage of funds.

Having thus established the general chronologies of the strikes, let us now attempt to analyze the techniques employed by our two classes of workers. We want to compare and contrast the methods of labor unrest of the weavers with those of the spinners in terms of the two industrial structures outlined in the introduction.

${ }^{1}$ E. C. Tufnell, Character, Object, and Effects of Trades' Unions (London, 1834), p. 14.

${ }^{2} \mathrm{HO} 42 / 178$, Aspinall, No 231, p. 250.

- Report on Artizans and Machinery, op. cit., p. 575. 


\section{II}

As indicated in the above narrative, violent assaults upon factories were common during the strikes of the cotton spinners. Threats of such attacks appear to have been held out to those employers who showed inclinations to hire strike-breakers or assist the authorities in prosecuting the strikers under the Combination Acts. Mr Gray, for example, was one of the bolder employers, who tried to keep his mill open during the 1818 strike. To assist Gray, Sir John Byng, commander of the soldiers of the Northern district, stationed his troops outside the establishment. However, the day after the soldiers were withdrawn an attack by about 700 persons was made on the factory during, which all the windows were broken and the door panels smashed in. ${ }^{1}$ Factory owner James Frost, in relating this incident to the 1824 Parliamentary Committee on Artizans and Machinery, recalled that Gray had been expecting an attack for several days and had thus equipped his mill with fowling pieces, stones, and a few pistols. ${ }^{2}$ Frost himself attempted to keep his factory in operation and was dragged into the street by some of the strikers and severely beaten. He identified one of his assailants, who was subsequently taken into custody. After witnessing the assault on Gray's mill, however, Mr Frost was seemingly unwilling to push things too far and thus interceded on behalf of his attacker, who was then released from jail on his own recognizance. ${ }^{3}$ Frost noted, moreover, that many other establishments were attacked in 1818, although the extent of damage was usually not as great as that at Gray's because most other mills were not attempting to employ as many workers during the strike. ${ }^{4}$

Some assaults, however, were of a very serious nature. For instance, on July 26, 1818, Colonel Fletcher informed Henry Hobhouse that two mills had been set on fire. Among the largest losses was that of Messrs Ormrod and Hardcastle of Bolton, who saw their $£ 30,000$ factory burn to the ground. ${ }^{5}$ Needless to say, those employers who were persuaded by the magistrates to keep their factories open did so only under the assurance of police protection. ${ }^{6}$ But shortly after some such experiments were tried, it was still noted that "many of the manufacturers do not think fit to keep their workshops open". " Specific references to attacks upon mills in 1810 are lacking, but E. C. Tufnell, author of

1 Ibid., p. 577.

2 Ibid.

3 Ibid., p. 576.

4 Ibid., p. 577.

${ }^{5} \mathrm{HO} 42 / 178$, Aspinall, No 232, p. 251.

${ }^{6} \mathrm{HO} 42 / 179$, Aspinall, No 238, pp. 263-64.

7 HO 79/3/234-36, Aspinall, No 254, p. 270. 
the most comprehensive contemporary account of that year's strike, noted that such acts were frequent. ${ }^{1} \mathrm{Mr} \mathrm{J}$. Jones told the Committee on Artizans and Machinery that in 1810 his mill was, in fact, assaulted with many windows being broken. ${ }^{2}$

While the factory employers were thus compelled not to hire strikebreakers, it is also clear that they were no more enthusiastic about identifying the strike leaders to the authorities. Indeed, the Home Office is full of complaints from magistrates over the employers' refusals to cooperate with them. Henry Hobhouse lamented on August 11, 1818: "Everybody here concurs with you [Rev. W. R. Hay, JP of Ackworth] in feeling the injury which has been done at Manchester by the backwardness of the masters. How is it possible for any Government to protect men who will not protect themselves?'”3 Rev. Hay, however, felt that protection was uppermost on the masters' minds, judging that "they are collectively and individually frightened". "In fact, James Frost observed that, upon the seizure of the 1818 strike committee, most of the Union leaders were shown lenience through the intercession of their employers. ${ }^{5}$ When asked what effect the Combination Acts had in obstructing the striking spinners in 1810, Frost summed up the views of the other testifiers: "The Combination Laws had no effect whatever in putting them down." 6 It is clear that many of the factory owners felt that the Combination Acts were sources of more trouble than they were worth, serving only to frustrate relations between employer and worker. ${ }^{\text {? }}$

These acts of intimidation by the spinners should be viewed in contrast to those of the handloom weavers. While the spinners attacked their employers' most conspicuous possessions, the factories, the striking handloom weavers directed their hostilities towards other weavers who had quit the strike. For instance, on June 4, 1808, with many weavers already returning to work, Thomas Drake, JP of Rochdale, could write to the Home Office that "an outrageous mob of several thousands broke open the private houses of weavers, carried off their shuttles and other implements of weaving". " William Longson,

1 Tufnell, Character, Object, and Effects, op. cit., p. 14.

2 Report on Artizans and Machinery, p. 577.

${ }^{3}$ HO 79/3/299-30, Aspinall, No 248, p. 268.

4 HO 42/178, Aspinall, No 236, p. 259.

5 Report on Artizans and Machinery, p. 577.

Ibid., p. 609.

${ }^{7}$ M. D. George has, in fact, argued against the supposed oppression of the Combination Acts, emphasizing their lack of enforcement. See "The Combination Laws Reconsidered", in: Economic Journal (Economic History Supplement), I (1929), pp. 214-28.

${ }^{8}$ HO 42/95, Aspinall, No 95, p. 100. 
a Manchester weaver, described such an assault made upon his own establishment in 1818: "Some one came in the night, and broke the windows, and by that means got the vitriol through; our shops in which we weave in Lancashire are in general cellars; it was easily done." 1 However, the most distinct display of violence in the weavers' strike of 1818 occurred in Northern Lancashire during the second week of September, after the weavers of Manchester had given up their strike. Apparently the tactic adopted by the districts in this area was to take the names of those who showed an inclination to work, visit their homes, and threaten them with fire. ${ }^{2}$ Both in 1808 and 1818 the appearance of strong military forces and regular patrols of the streets by special constables were seen by the authorities as necessary to protect those who wished to work. Thus while the spinners sought to frustrate strike-breaking and enforcement of the Combination Acts by threatening their employers with destruction of their property, the handloom weavers found it necessary to intimidate their fellow workers in attempting to enforce their movements.

To arrive at the significance of these differing forms of unrest we should now look at the structures of the weaving and spinning industries. Although workers under the domestic system of manufacturing had long since relinquished ownership of raw material and thus sold their labor rather than its product, fixed capital (machinery and buildings) tended to remain in the possession of the laborer. Exceptions in the weaving industry can be found in the handloom weaving "factories" or sheds. In this case, the looms, while not power-driven, were owned by the employer, who set them up in his own workshop. But it does not appear that such establishments accounted for a very large proportion of handloom weaving Lancashire. ${ }^{3}$ Typically, all the employer needed in the way of buildings was a warehouse to store and sell his goods, and unless he owned a weaving shed, he was not responsible for the looms which belonged to the individual worker. For instance, the 1795 balance sheet of the Birley, Cardwell, and Hornby weaving firm reports that of $£ 182,924$ in total assets, fixed capital accounted for only $£ 160$, most of the investment being in the form of stock and credits due from debtors. ${ }^{4}$ Therefore, with manufacturing for the most part domestically based, the capitalist-employer was not as easily identifiable to the worker

1 Report on Artizans and Machinery, p. 359.

2 HO 42/180, Aspinall, No 302, p. 300.

${ }^{3}$ Duncan Bythell, The Handloom Weavers (Cambridge, 1969), pp. 33-36.

4 Michael Edwards, The Growth of the British Cotton Trade 1780-1815 (Manchester, 1967), p. 257. 
as was the factory owner. Generally a handloom weaver saw his employer only when receiving yarn and returning cloth for payment. We have seen that in order to enforce compliance with a strike the weavers sought to halt the movement of looms; but in doing so they were threatening the capital of their fellow workers and were thus not likely to put much pressure on the capitalist-employer.

In cotton spinning, however, ownership of the new machinery passed, with the Industrial Revolution, to the employer; moreover, manufacturing was diverted from the home into the factory, another possession of the employer. Therefore, fixed capital represented a much larger investment for the mill owner than it did for the putterout. The 1802 balance sheet of the F. Simpson spinning concern shows that of $£ 171,041$ in total assets, the mill and machinery accounted for $£ 30,000 .{ }^{1}$ The firm of Greg and Ewart, one of those attacked in 1818, reported in 1814 that buildings and machinery represented $£ 5,158$ of its total investment of $£ 14,158 .^{2}$ Similarly, the 1800 Sedgwick mill represented $£ 21,838$ of investment, ${ }^{3}$ while Kennedy's Manchester factory was valued at $£ 18,15214 /$ in $1809 .{ }^{4}$

Working for as many as 12 hours per day in their employers' establishments and on their machinery, the factory worker could easily identify the capitalist, and we have seen how the spinners used violence or its threat as a lever of pressure against the mill owner to ensure that he did not keep his factory open or identify the strike leaders to the authorities. While the weaving entrepreneur suffered little by the destruction of working looms in a strike, the spinning employer, if he interfered with a strike movement, risked an immense capital loss. Therefore, it appears that as labor and the possession of capital became more completely alienated with the rise of the factory system, labor unrest could and did assume a distinctly anti-capitalistic nature.

Just as the clearer differentiation between capital control and labor gave rise to a more militantly anti-capitalistic nature of unrest among the spinners, so this sharper definition of labor implied a growing sense of solidarity within the factory working force. It is certainly true that the handloom weavers, in their strikes of 1808 and 1818 , demonstrated considerable degrees of cohesiveness during the early days of the movements and in the crescent of towns around Manchester. The meetings on St George's Field on May 24 and 25, 1808 and the parades

1 Ibid., p. 258.

${ }^{2}$ Ibid.

Ibid., p. 189.

4 C. W. Daniels, "The Early Records of a Great Manchester Cotton-Spinning Firm", in: Economic Journal, XXV (1915), p. 176. 
through the streets of Manchester during the first day of the 1818 strike impressed contemporaries with their displays of solidarity. However, in both years the weavers of Northern Lancashire came out and stayed out later than the strikers in the Manchester vicinity, and we have just noted how their movements ended in violence among the workers.

By contrast, the spinners' unions were noted for their superior organization. Tufnell declared emphatically that the "best organized Union in the kingdom, appears to be that of the working cotton spinners". ${ }^{1}$ The coordination of the spinners' strikes of 1810 and 1818 , in fact, vividly reveals this trait. Unlike the handloom weavers, the spinners all struck on the same day. The Union Congress of 1810 , composed of representatives from the various mills, and the $\mathbf{1 8 1 8}$ system of sending spinners from factory to factory to prevent strikebreaking indicate a degree of intercourse between workmen that was conspicuously absent from the movement of the handloom weavers.

But the problem of worker solidarity is perhaps best revealed by the system of mutual support embodied in the strike fund. It stands to reason that, in their chronically depressed condition, the weavers would have a difficult time in sustaining a strike fund. Based upon contemporary accounts, economic historian J. H. Clapham has concluded that a Manchester weaver could only earn from $6 / 6 \mathrm{~d}$ per week to $9 /$ - per week during the 1820 's. By contrast, a cotton spinner could expect to earn from $24 /$ - per week to $44 / 6 \mathrm{~d}$ per week during the same years. ${ }^{2}$ As a Manchester weaver noted, "They [the weavers] are so impoverished that if they give a halfpenny out of their pockets they must work for it again, and they will not give aid to other men."3 Although it appears that the handloom weavers drew financial support from their benefit societies in 1808 and 1818, it is doubtful that it amounted to much. ${ }^{4}$ In fact, a little more than a week after the start of the 1818 strike, the weavers found it necessary to appeal to the public for subscriptions. ${ }^{5}$

The spinners, as the longevity of their strikes indicates, were better able to support their men. Mr James Frost figured that the spinners' fund for the 1810 strike contained between $£ 1,000$ and $£ 1,500$ per week,

1 Tufnell, Character, Object, and Effects, p. 2.

2 J. H. Clapham, An Economic History of Modern Britain, I (Cambridge, 1926), pp. 550-53.

3 Report on Handloom Weavers' Petitions, op. cit., p. 505.

4 HO 42/95 and 180, Aspinall, Nos 100 and 302, pp. 102, 300. Unfortunately, we have no exact figures on the size of the funds, merely the impressions of contemporary observers.

5 For the complete text of the appeal, see Aspinall, No 294, p. 294. 
and was subsidized by all the manufacturing towns. ${ }^{1}$ For instance, during one week Manchester donated $£ 606$, $£ 62$ of which went to Preston. Also contributing to Preston's fund were Stockport £10; Macclesfield, $£ 10$; Carlisle, $£ 20$; and Oldham, £20, for a total of $£ 122$ paid to Preston. Similarly, in the same week Staley Bridge received $£ 363$ from Manchester, $£ 40$ from Bolton, and $£ 17$ from Chorley. Mr Frost also observed that the 1810 fund was supported by those spinners still at work and was able to pay each striker 14/- per week, although he didn't mention for how long this division was maintained. Generous support from the various spinning districts was also noted during the 1818 strike. In fact, as late as August 20,1818, one month after the beginning of the movement, Henry Hobhouse could write from Whitehall that it was still "a very curious problem from whence the great supply of money has been made to the workmen who have thrown themselves out of work, and any light will be valuable that can be thrown on that question". ${ }^{2}$ It was not until August 28 that the 1818 spinners' fund was broken up, and as late as September 7 the spinners were able to sustain their strike.

Moreover, in the 1818 movement a further development could be noted: outside support from other trades. With the strike just under way, Mr Norris exclaimed:

"The system of support from one trade to another is carried on to an amazing extent, and they [the spinners] regularly sent delegates out to the different towns who are in work to receive their subscriptions." 3

On August 12, 1818, W. S. Kinnersly, JP of Newcastle, reported that the journeymen hatters had held a meeting for the purpose of lending support to the striking spinners in Manchester. He observed: "The sum was trifling, being only $£ 5$ from five to six hundred men, but important as shewing the system." 4 Among the larger contributors were the tailors of London, who reportedly lent $£ 600$ at one time. ${ }^{5}$ Also donating money to the movement were the millwrights, the calico printers, the fustian cutters, and the London shoemakers. ${ }^{6}$ Finally, the 1818 striking spinners were aided in their efforts by shopkeepers. For example, Norris reported that "One small huckster near the

1 For a complete listing of the contributions, too lengthy to print here, see Report on Artizans and Machinery, pp. 604-07.

${ }^{2}$ HO 73/3/260, Aspinall, No 261, p. 274.

${ }^{3} \mathrm{HO} 42 / 178$, Aspinall, No 234, p. 254.

${ }^{4}$ HO 42/179, Aspinall, No 252, p. 269.

${ }^{5}$ HO 42/179, Aspinall, No 247, p. 267.

- J. L. and B. Hammond, The Skilled Labourer (London, 1919), p. 103. 
factories has given credit to the men to the amount of $£ 250$."' Altogether, he calculated a sum of no less than $£ 4,500$ from various societies of workmen throughout the kingdom. ${ }^{2}$

In explaining these developments we should again turn to the structure of the cotton industry in the early 19th century. It has already been shown that, owing to the fuzzy distinction between labor and the possession of capital in putting-out manufacturing, the striking weavers directed violence and its threat towards the property of the workers as they attempted to discourage the use of scab labor. Such a mechanism would hardly be conducive to the development of worker solidarity. Furthermore, it is clear that a large source of the weavers' organizational problems was the dispersed nature of their industry. A Scottish handloom weaver, commenting in 1834, expressed the problem as follows: "We being scattered over the whole face of the country cannot communicate with each other, and we are easily routed by our masters." 3 In such a situation communication between the weavers was more apt to be hindered by geographical features than it was for the relatively concentrated spinners. Professor Bythell, for instance, sees the hills of Rossendale as a barrier to intercourse between the Manchester area and the calico weavers of Northern Lancashire. ${ }^{4}$ During the 1808 strike, the Bolton weavers, separated by approximately ten miles of moorland from the neighborhood of Blackburn, sent a letter to the weavers in that area advertising a general delegate meeting of weavers and expressing mere "hope that our brethren will join them". ${ }^{5}$ Therefore, just as trade-union militancy was hindered by the difficulty of identifying and applying pressure to the capitalist, so the problem of achieving solidarity within the cottage industry was intensified by its dispersed nature.

The spinning labor force, on the other hand, was more concentrated under the factory system. Michael Edwards in Growth of British Cotton Trade, 1780-1815, has shown that by no means were all factories large and elaborate structures, noting that a late-18th-century mill could be almost any old building. Very often corn mills and private dwellings were stocked with spinning jennys and even mules run by steam. ${ }^{6}$ Nevertheless, the trend of factory development from the late 18th through the early 19th centuries was to concentrate the working

1 HO 42/179, Aspinall, No 251, p. 268.

${ }^{2}$ HO 42/180, Aspinall, No 298, p. 299.

3 Report on Handloom Weavers' Petitions, p. 41, cited in Bythell, The Handloom Weavers, op. cit., p. 178.

4 Bythell, op. cit., p. 187.

5 HO 42/95, Aspinall, No 96, p. 100.

6 Edwards, The Growth of the British Cotton Trade, op. cit., pp. 186-88. 
force. Statistical returns on the numbers employed in various factories are very incomplete, but only a few examples are needed to make the point. While Henry Ashworth's mill, still in its infancy by 1820, was at that time employing only 120 persons, ${ }^{1}$ John Kennedy's Manchester factory gave work to 1,150 operatives in $1819,{ }^{2}$ and $\mathrm{Mr} W$. Bolling estimated that his factory in Bolton employed some 1,000 people in $1824 .{ }^{3}$ Professor Edwards has also noted that not all mills were located in large manufacturing towns. Ashworth's New Eagly Mill, for instance, was situated in the Lancashire countryside, about four miles from Bury, the nearest town. ${ }^{4}$ However, with the increasing use of steam power after 1800 , the clustering of factories in urban industrial centers became evident. The most thorough set of statistics for the year 1811 was compiled by Samual Crompton, who counted no less than 650 mills within a 60 mile radius of Bolton. ${ }^{5}$ Contemporary historian Edward Baines estimated in 1824 that there existed 21 cotton factories in Bolton, 40 in Preston, and 104 in Manchester, while the town of Blackburn was giving employment to some 10,000 persons working on 100,000 spindles. ${ }^{6}$

Thus the spinners, brought together in large numbers to labor in their employers' factories, were in a better position to organize their movements against the capitalists and to lend financial support to one another in a strike than were the more dispersed handloom weavers. John Makin, a weaver testifying before the Select Committee on Handloom Weavers in 1834, certainly noted the development; when asked to give a reason why the wages of the spinners had not fallen in the same manner as those of the weavers, he replied: "The spinners being assembled more under one roof are more capable of combining, and by combination they have opposed a barrier to reduction." 7 The examination of $\mathrm{Mr} \mathrm{J}$. Jones, a factory owner, expresses the same view:

"Q. Are not the spinners collected together in one manufactury, whilst the weavers are out in different houses? - Yes.

Q. May not that influence a good deal the facility of combination? - It does."8

1 Rhodes Boyson, The Ashworth Cotton Enterprise (Oxford, 1970), p. 14.

2 Daniels, "The Early Records", loc. cit., p. 178.

${ }^{3}$ Report on Artizans and Machinery, p. 555.

4 Boyson, op. cit., map, p. 2.

'C. W. Daniels, "Samuel Crompton's Census of the Cotton Industry in 1811", in: Economic Journal (Economic History Supplement), II (1930), p. 108.

${ }^{6}$ Edward Baines, History of the County Palatine and the Duchy of Lancashire (Liverpool, 1825), p. 533, 485, 134.

7 Report on Handloom Weavers' Petitions, p. 419.

8 Report on Artizans and Machinery, p. 561. 
Moreover, outside support from other trades indicates that the gradual urbanization of the factory system was stimulating identification among various classes of workmen. In sum, it appears that as workers under the factory system were militantly expressing their relations with the capitalist-entrepreneurs, they were also becoming solidified as a class.

\section{CONCLUSIONS}

Although the Lancashire cotton workers failed to attain their ultimate objectives in their strikes before 1824, it is clear that worker unrest in the period of the Combination Acts should be seen as an integral stage in the growth of the English labor movement. For the years 1800-24 were ones of the developing Industrial Revolution in the cotton manufacture, and we have seen that the factory workers in the spinning industry responded to this trend by adopting progressive methods of agitation. By contrasting the mechanisms of strike enforcement among the spinners with those of the domestically based handloom weavers, this study has attempted to show how the growing differentiation between the roles of capital control and labor induced the rise of militantly anti-capitalistic techniques of unrest among the factory workers. The weavers, who had retained possession of the fixed capital, could not hope to apply much pressure to the capitalist by attacking moving looms during their strikes. But the spinners, as we have noted, caused no small amount of concern among their employers by threatening to destroy their establishments if they sought to break the strike by hiring scabs or if they tried to aid the authorities in arresting the union leaders under the Combination Laws.

Moreover, while the handloom weavers were not in a position to harm the capitalist by assaulting working looms, it is also evident that such a mechanism was bound to destroy the cohesiveness of the laboring force. We have seen how the weavers' strikes ended with acts of violence between those still out of work and the operatives who had quit the movement. Furthermore, the lack of efficient communication and coordination among the weaving districts reveals how the attainment of worker solidarity was further hindered by the dispersed nature of the rural-domestic weaving industry. On the other hand, the complete separation of capital ownership from labor in the spinning industry had provided the factory workers with a common lever of pressure which was less likely to split the striking body. And their techniques of organization and mutual financial support indicate that the concentrating effects of the factory system also helped the spinners to maintain cohesion among themselves and to bring them into contact 
with laborers in other trades. It thus seems clear that, despite the laws against unions, very early in the process of industrialization the new factory workers were coming to identify themselves with the large body of proletarians as a class with interests distinct from those of the rising capitalist-entrepreneurs. 